\title{
Effect of Potassium Dichromate on Properties and Biodegradation of Gum Arabic Based Bioplastic Membranes
}

\author{
Sherif S. Z. Hindi ${ }^{1, *}$, Mona O. Albureikan ${ }^{2}$, Attieh A. Al-Ghamdi ${ }^{3}$, Haya Alhummiany ${ }^{4}$, Sana M. Al-Sharabi ${ }^{2}$ \\ ${ }^{1}$ Department of Arid Land Agriculture, Faculty of Meteorology, Environment and Arid Land Agriculture, King Abdulaziz University, \\ P.O. Box 80208, Jeddah-21589, Saudi Arabia \\ ${ }^{2}$ Department of Microbiology, Faculty of Science, King Abdulaziz University \\ ${ }^{3}$ Department of Physics, University of Jeddah, Saudi Arabia \\ ${ }^{4}$ Department of Physics, Faculty of Science, Al-Faisaliah Campus, King Abdulaziz University \\ *Corresponding author: shindi@kau.edu.sa
}

\begin{abstract}
Gum Arabic (GA) collected from Acacia senegal trees was used with polyvinyl alcohol (PVA) to prepare of a series of biodegradable membranes doped and non-doped with potassium dichromate $\left(\mathrm{K}_{2} \mathrm{Cr}_{2} \mathrm{O}_{7}\right)$. Adding the $\mathrm{K}_{2} \mathrm{Cr}_{2} \mathrm{O}_{7}$ to the GA/PVA blends slightly decreased their crystallinity index (CI) by about 2 \%. Increasing the PVA concentration in the chromated GA/PVA blends was responsible for increasing the CI. Adding the $\mathrm{K}_{2} \mathrm{Cr}_{2} \mathrm{O}_{7}$ to the pure GA solution modified its differential thermal behavior whereby the exothermic reactions occurred between $321^{\circ} \mathrm{C}$ and $433^{\circ} \mathrm{C}$ were disappeared. The $\mathrm{K}_{2} \mathrm{Cr}_{2} \mathrm{O}_{7}$ increased the heat change drastically for all the bioplastic blends with the highest increase for the pure GA. Adding $\mathrm{K}_{2} \mathrm{Cr}_{2} \mathrm{O}_{7}$ to the pure PVA increased the nanometric particle size (NPS) significantly. Increasing the PVA concentration in a blend had a greater effect than did the $\mathrm{K}_{2} \mathrm{Cr}_{2} \mathrm{O}_{7}$ on the NPS. The buried bioplastic membranes in the control soil had different count and species of microbial communities. The numbers of bacteria and fungi in the initial soil sample were lower than those for chromated GA membranes and were greater than those for the chromated PVA. All bacterial and fungi species had growth ability and are expected to be detoxification tools of chromium ion-doped blends of GA and PVA leading to a green environment.
\end{abstract}

Keywords: arabic gum, polyvenyl alcohol, potassium dichromate, bio-degradation

Cite This Article: Sherif S. Z. Hindi, Mona O. Albureikan, Attieh A. Al-Ghamdi, Haya Alhummiany, and Sana M. Al-Sharabi, "Effect of Potassium Dichromate on Properties and Biodegradation of Gum Arabic Based Bioplastic Membranes.” Nanoscience and Nanotechnology Research, vol. 4, no. 2 (2017): 49-58. doi: 10.12691/nnr-4-2-3.

\section{Introduction}

Potassium dichromate $\left(\mathrm{K}_{2} \mathrm{Cr}_{2} \mathrm{O}_{7}\right)$ known as chromic acid, has a wide range of uses including oxidization in many chemical applications such as dyeing, staining tanning of leather as well as in composite materials. It is also used medically as an external antiseptic or astringent and is present in some veterinary medications. It was found that treating jute fabrics-composites with 0.005$0.03 \% \mathrm{w} / \mathrm{v} \mathrm{K}_{2} \mathrm{Cr}_{2} \mathrm{O}_{7}$ showed better performance, higher thermal stability and superior mechanical properties than those of the control composite. In addition, the tendency of water uptake of the composite was also reduced due to $\mathrm{K}_{2} \mathrm{Cr}_{2} \mathrm{O}_{7}$ treatment. The great improvement in the thermal stability of the composite was attributed to the development of strong fiber-matrix interface [1]. Potassium dichromate solution was used to improve the hydrophilicity of polyglycolide or polyglycolic acid and poly(lactic-co-glycolic acid) fibers by compensating the lack of hydrophilic groups on their surfaces and preserving fiber mechanical property at the same time [2].
Crystallinity is a case of molecular structure among a long range periodic geometric pattern of atomic spacings. In semicrystalline polymers, the degree of crystallinity (crystallinity index, \%) influences the degree of stiffness, hardness and heat resistance. In semicrystalline polymers, some of their macromolecules are arranged as crystallites immersed in an amorphous matrix. The greater the concentration of these crystallites, the greater the crystallinity and subsequently more rigidity were obtained for the polymer [3].

Many researchers have reported the capability of bacterial and fungi species to degrade the polyvinylalcohol or gum Arabic easily [4,5,6,7,8]. It was showed that GA and PVA may blended together or with other natural polymers to improve their biodegradability, properties, and for producing nontoxic phytochemical scaffold which have therapeutic and diagnosis treatments applications [9,10,11,12,13]. Moreover, in the industrial applications field, solution of gum Arabic is mixed with either potassium or ammonium dichromate as a way of making photographic reproductions, and this is called gum printing [14]. Chromium compounds are used 
commercially in industrial welding, metal finishes, leather tanning, and wood preservation [15]. The chromium ion is considered as one of heavy metals that are very essential for biochemical and physiological functions in plants and animals [16]. Although chromium is an essential micronutrient for the growth of many organisms, but at high concentration it is toxic, carcinogenic and cause allergic $[17,18,19,20]$. Potassium dichromate has many harmful and toxic effects on mammals and rats [16]. For example, toxic effects of potassium dichromate on sex hormones of female albino rats [21], respiratory cancers $[17,22]$, and ototoxicity that cause a wide range of fetal effects [23]. Fortunately, many microbial species have the ability to breakdown a variety of chemical compounds, including aliphatic and aromatic hydrocarbons, fatty acids, insecticides and potassium dichromate, which make them useful for a bioremediation of environmental pollutants [24]. This means that microorganisms can play an important role in the detoxification of potassium dichromate from the polluted places by modifying their chemical and/or physical characteristics and that because the bacteria and fungi species can use chromium (VI) as terminal electron acceptor during oxidation of organic compound [25,26,27]. It was reported that Bacillus sp. [25,28], Escherichia coli [29], Pseudomonas sp. [30,31], Staphylococcus aureus IFR-2, and Pediococcus pentosaceus IFR-3 [32], are the most bacterial strains having the abilities for detoxification of potassium dichromate, while Penicillium sp., Rhizopus sp., Aspergillus sp. were the most strains of fungi possessing this ability $[33,34]$.

\subsection{Objectives}

The aim of the current research is to study the effects of potassium dichromate on crystallinity index, mass loss, thermal stability, nanoparticle size and biodegradation of gum Arabic based bioplastic membranes with different ratios of GA and PVA treated and untreated with potassium dichromate.

\section{Experimental}

\subsection{Raw Material}

Gum Arabic (GA) with molecular weight (about Mw: $\left.1.827 \times 10^{6} \mathrm{~g} / \mathrm{mole}\right)$ was collected from Acacia senegal trees habitated at Hada Al-Sham (about $120 \mathrm{~km}$ apart from Jeddah). The GA was used to prepare of twelve bio-plastic membranes beside ACS reagents of polyvinyl alcohol (PVA, Mw 88000, 88\% deacetylated) and potassium dichromate $\left(\mathrm{K}_{2} \mathrm{Cr}_{2} \mathrm{O}_{7}, 99 \%\right)$ that were purchased from Sigma-Aldrich, USA. Deionized water was used throughout.

\subsection{Preparation of Precursor Solutions}

$5 \mathrm{wt} \%$ aqueous solutions of each of AG, PVA and $\mathrm{K}_{2} \mathrm{Cr}_{2} \mathrm{O}_{7}$ were prepared in deionized water as shown by Hindi et al. [35].

For the aqueous solution of the GA, the crude granules of the GA were dissolved in deionized water at $80^{\circ} \mathrm{C}$ with continuous stirring until all the granules were disappeared.
The clear solution was obtained by removal of insoluble components by vacuum filtration using 120 mesh standard screen.

Two groups of blends were synthesized by mixing different ratios of GA/PVA, namely chromated nonchromated bioplastic membranes by using $5 \mathrm{wt} \%$ aqueous solutions according to the different weight ratios shown in Table 1. The stirring process must be calm to ensure non-introducing much air bubbles into the solution and be extended until obtaining the adequate homogeneity. The bubble free ternary blend solution was poured onto a cleaned acrylic panel (polymethyl methacrylate) with a prominent frame and allowed to be evaporated at room temperature. The membrane thickness was controlled by pouring a definite quantity of blend solution. The acrylic panel was chosen due to its non-sticky characteristic with the blended polymers and the membranes can be easily peeled off the panels after curing and drying. The peeled membranes were kept in vacuum desiccators until utilization.

Table 1. GA/PVA ratio and precursor allocation in $100 \mathrm{~mL}-b l e n d$ of bioplastic membrane synthesized from three $5 \% \mathrm{wt} / \mathrm{wt}$-aquous precursors of gum Arabic (GA), polyvinyl alcohol (PVA) and potassium dichromate $\left(\mathrm{K}_{2} \mathrm{Cr}_{2} \mathrm{O}_{7}\right)$

\begin{tabular}{cc|ccc}
\hline \multirow{2}{*}{$\begin{array}{c}\text { Formula } \\
\text { No. }\end{array}$} & $\begin{array}{c}\text { AG/PVA } \\
\text { ratio }\end{array}$ & $\begin{array}{c}\text { Precursor allocation in } 100 \mathrm{~mL} \\
(\mathrm{~mL})\end{array}$ & $\begin{array}{c}\mathrm{PVA} \\
(\mathrm{mL})\end{array}$ & $\begin{array}{c}\mathrm{K}_{2} \mathrm{Cr}_{2} \mathrm{O}_{7} \\
(\mathrm{~mL})\end{array}$ \\
\cline { 3 - 5 } 1 & $1: 0$ & 100 & 0 & 0 \\
2 & $1: 0.25$ & 80 & 20 & 0 \\
3 & $1: 0.5$ & 66.7 & 33.3 & 0 \\
4 & $1: 0.75$ & 57.1 & 42.9 & 0 \\
5 & $1: 1$ & 50 & 50 & 0 \\
6 & $0: 1$ & 0 & 100 & 0 \\
7 & $1: 0$ & 85 & 0 & 15 \\
8 & $1: 0.25$ & 68 & 17 & 15 \\
9 & $1: 0.50$ & 56.7 & 28.3 & 15 \\
10 & $1: 0.75$ & 48.57 & 36.43 & 15 \\
11 & $1: 1$ & 42.5 & 42.5 & 15 \\
12 & $0: 1$ & 0 & 85 & 15 \\
\hline
\end{tabular}

\subsection{Characterization}

\subsubsection{X-Ray Diffraction (XRD)}

The XRD spectra of the bioplastic membranes were measured by using XRD 7000 Shimadzu diffractometer (Japan) according to Hindi [36]. The system has a rotating anode generator with a copper target and wide angle powder goniometer. The system was performed using $\mathrm{CuK} \alpha$ radiation generated at $30 \mathrm{kV}$ and $30 \mathrm{~mA}$. The $\mathrm{CuK} \alpha$ radiation consists of $K \alpha_{1}(0.15406 \mathrm{~nm})$ and $K \alpha_{2}(0.15444$ $\mathrm{nm})$ components, and the resultant XRD data has both components. The $\mathrm{CuK} \alpha$ radiation is separated from the data using a single-channel analyzer on the output from the semiconductor detector. Each of the divergence and scatter slits was $1^{\circ}$ and the receiving slit was $0.15 \mathrm{~mm}$ at the same radius. Dried bioplastic samples (about $0.5 \mathrm{~g}$ ) were mounted onto a quartz substrate using amorphous glue. All samples were scanned in $2 \theta^{\circ}$ range differed from $10^{\circ}$ to $30^{\circ}$. All the measurements were performed in the reflection mode at a scan speed of $4^{\circ} / \mathrm{min}$ in steps of $0.05^{\circ}$. 


\subsection{Thermal Analysis}

This characterization was done for the six formulas. The Thermogravimetric analysis (TGA) and differential thermal analysis (DTA) for each formula was performed by using a Seiko \& star 6300 analyzer, Central Laboratory, Faculty of Science, Alexandria University, Egypt. Heating scans from 30 up to $550^{\circ} \mathrm{C}$ at $20^{\circ} \mathrm{C} / \mathrm{min}$ in nitrogen atmosphere were performed for each sample [37].

\subsubsection{Surface Roughness (SR)}

The SR was investigated by atomic force microscopy (AFM) to study the surficial roughness by Omicron VT AFM. XA [35].

\subsubsection{Biodegradation by Bacteria and Fungi}

The bioplastic samples were buried in a soil that obtained from Hada Al-Sham at the Agricultural Research Station (ARS) of the Faculty of Meteorology, Environment and Arid Land Agriculture of King Abdullaziz University. The $\mathrm{pH}$ of soil in this site is ranging from 7.1 to 7.9 , and the organic matter, $\mathrm{CaCO}_{3}$ and cation exchange capacity were low.

\subsubsection{Isolation of Microbial Communities}

Only one gram of each soil sample was suspended in sterile distilled water. Then, the supernatant was diluted among six tubes by serial dilution method and $1 \mathrm{ml}$ from each dilution was plated in nutrient agar medium NA (Oxoid) for bacterial isolation while using potato dextrose agar medium PDA (Oxoid) for fungi isolates. After that, all the plates were incubated at $30{ }^{\circ} \mathrm{C}$ for $2-4$ days for the bacterial count and for $3-5$ days at $25^{\circ} \mathrm{C}$ to the fungal count. The isolated microorganisms were identified based on the cultural and morphological characters by using standard biochemical tests [38].

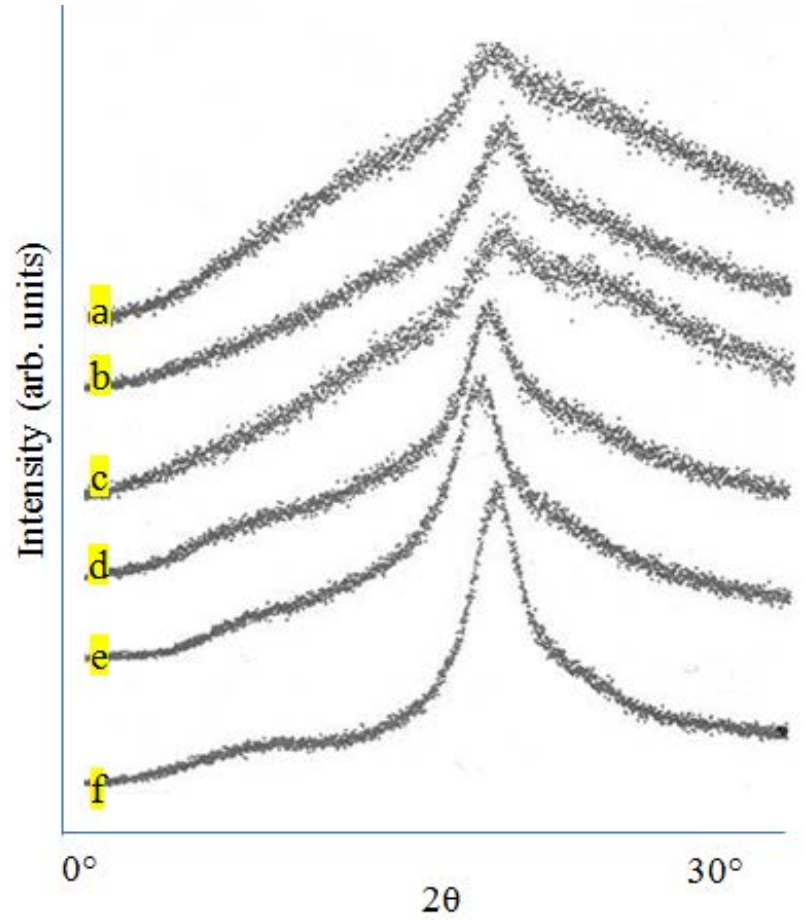

\subsubsection{Sample Preparation and Soil Burial Studies}

At a depth of $10 \mathrm{~cm}$, the different bioplastic samples were cut into $2 \times 2 \mathrm{~cm}$ pieces and buried in the soil that wear in boxes $(1 \mathrm{~L}) /$ sample. The weight for all pieces was between $0.040-0.038 \mathrm{mg}$ before being placed in the soil. All the soil boxes were placed in the laboratory, and the deionized water was added to adjust the soil moisture. Also, the excess water was excluded by a hole at the bottom of the boxes. After 30 days and 60 days, soil samples were taken carefully to isolate, count the microorganism's community, and to observe the degradation by morphological change in the samples surface $[13,39]$.

\subsection{Statistical Design and Analysis}

Randomized complete block design was used to evaluate the different properties of the bioplastic blended from twelve different formulas constituted from three aqueous solutions of Arabic gum (AG), Polyvinyl alcohol (PVA) and Potassium dichromate $\left(\mathrm{K}_{2} \mathrm{Cr}_{2} \mathrm{O}_{7}\right)$. Statistical analysis of the recorded data was done using the analysis of variance procedure and least significant difference test (LSD) at 0.05 according to El-Nakhalawy [41].

\section{Results and Discussion}

\subsection{X-Ray Diffraction (XRD)}

All the maximum intensities of the bioplastic membranes doped with $\mathrm{K}_{2} \mathrm{Cr}_{2} \mathrm{O}_{7}$ were obtained around $2 \theta=19^{\circ}$ except for the GA-diffractogram that was shifted to $2 \theta=22.34^{\circ}$ (Table 2) In addition, pure PVA known as a semi-crystalline polymer $[42,43]$ exhibited a sharper peak at $2 \theta=19.9^{\circ}$ (Figure 1 and Table 2).

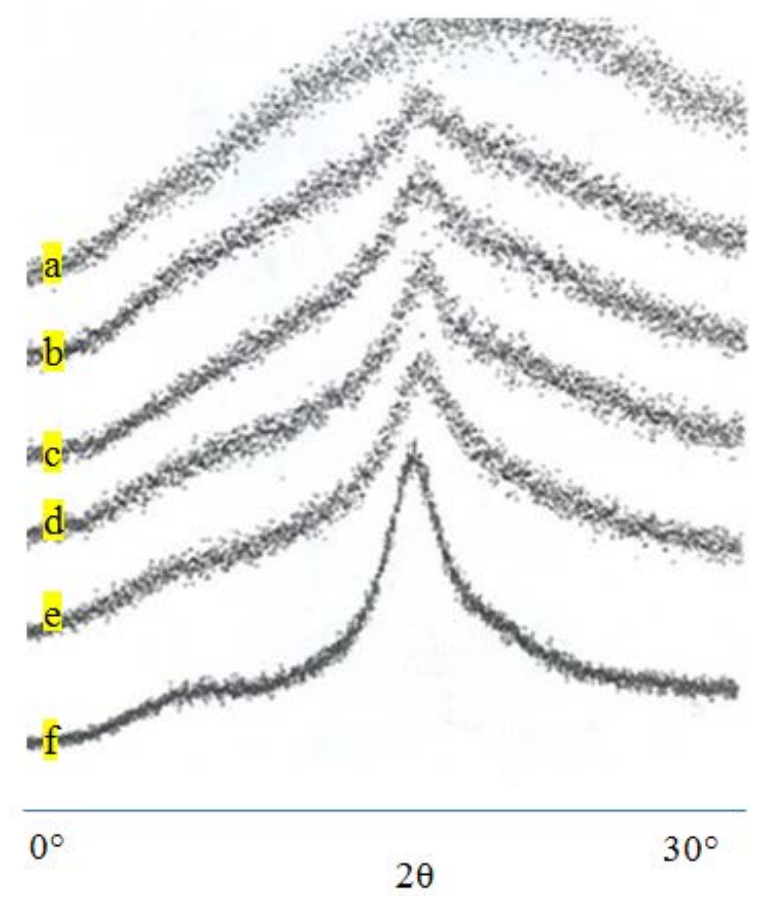

Figure 1. XRD dffractograms of the twelve bioplastic membranes blended from gum Arabic (GA) and polyvinyl alcohol (PVA) with different ratios, namely GA/PVA of: a) $1 / 0$, b) $1 / 0.25$, c) $1 / 0.5$, d) $1 / 1.75$, e) $1 / 1$, and f) $0 / 1$ in absence and presence of potassium di-chromate $\left(\mathrm{K}_{2} \mathrm{Cr}_{2} \mathrm{O}_{7}\right)$.in wavenumber range of 3500 to $500 \mathrm{~cm}^{-1}$ 
Table 2. XRD results ${ }^{1,2}$ of the principle peaks of the twelve bioplastic membranes blended from gum Arabic (GA) and polyvinyl alcohol (PVA) with different ratios, namely GA/PVA of: a) 1/0, b) 1/0.25, c) 1/0.5, d) 1/1.75, e) 1/1, and f) 0/1 in absence and presence of potassium dichromate $\left(\mathrm{K}_{2} \mathrm{Cr}_{2} \mathrm{O}_{7}\right)$.in wavenumber range of 3500 to $500 \mathrm{~cm}^{-1}$

\begin{tabular}{c|cc|cc}
\hline \multirow{2}{*}{ AG/ PVA/ $\mathrm{K}_{2} \mathrm{Cr}_{2} \mathrm{O}_{7}$ ratio } & \multicolumn{2}{|c|}{ Two Theta } & \multicolumn{2}{c}{ Maximum Intensity (Counts) } \\
\cline { 2 - 4 } & Non-chromated & Chromated & Non-chromated & Chromated \\
\hline $1 / 0$ & $19.989^{\mathrm{b}}$ & $22.34^{\mathrm{a}}$ & $977^{\mathrm{a}}$ & $518^{\mathrm{b}}$ \\
$1 / 0.25$ & $19.88^{\mathrm{a}}$ & $19.189^{\mathrm{a}}$ & $1768^{\mathrm{a}}$ & $1137^{\mathrm{b}}$ \\
$1 / 0.5$ & $20.231^{\mathrm{a}}$ & $19.637^{\mathrm{a}}$ & $1071^{\mathrm{a}}$ & $638^{\mathrm{b}}$ \\
$1 / 0.75$ & $19.843^{\mathrm{a}}$ & $19.443^{\mathrm{a}}$ & $845^{\mathrm{a}}$ & $745^{\mathrm{a}}$ \\
$1 / 1$ & $19.722^{\mathrm{a}}$ & $19.964^{\mathrm{a}}$ & $1272^{\mathrm{a}}$ & $673^{\mathrm{b}}$ \\
$0 / 1$ & $19.14^{\mathrm{a}}$ & $19.455^{\mathrm{a}}$ & $1622^{\mathrm{a}}$ & $779^{\mathrm{b}}$ \\
\hline
\end{tabular}

${ }^{1}$ Each value is an average of 3 samples.

${ }^{2}$ Superscripted small letters for comparisons between temperature zones.

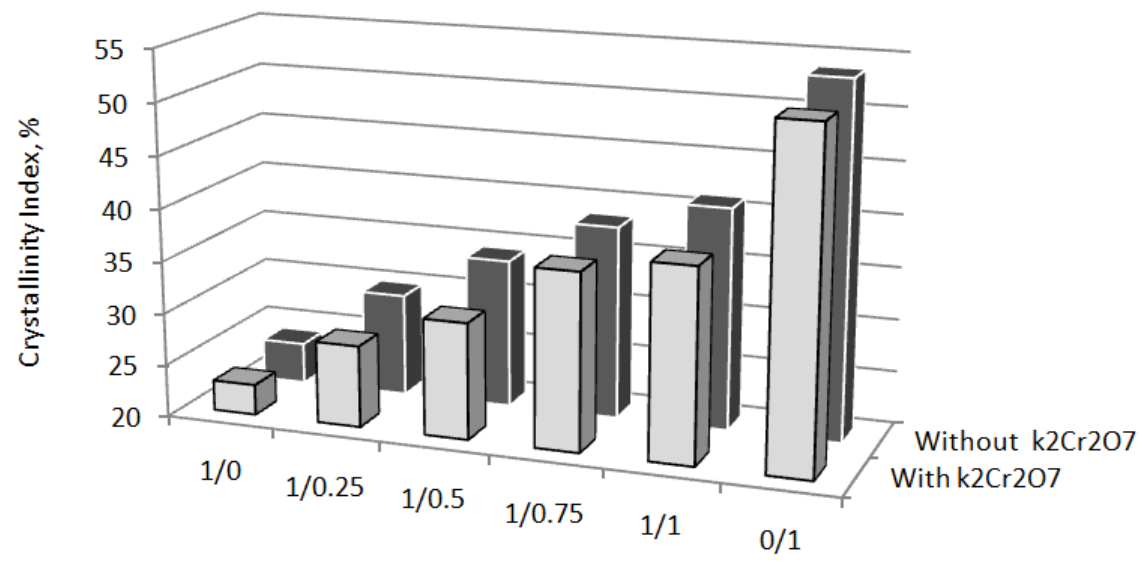

GA/PVA blends

Figure 2. Crystallinity index (CI) of the various bioplastic membranes made from the different gum Arabic (GA)/polyvinyl alcohol (PVA) and potassium dichromate $\left(\mathrm{K}_{2} \mathrm{Cr}_{2} \mathrm{O}_{7}\right)$ blends

\subsection{Crystallinity Index (CI)}

The XR-dffractograms presented in Figure 1 were used to determine the crystallinity indices of the bioplastic blends. For the bioplastic blends free of $\mathrm{K}_{2} \mathrm{Cr}_{2} \mathrm{O}_{7}$, the CI values were found to be increased from $22.9 \%$ (for pure GA) up to $51.9 \%$ (for pure PVA) as shown in Figure 2. Accordingly, it is clear that the increasing in the CI of the bioplastic blends can be attributed to the increasing of the PVA allocation in the blend. In addition, for the bioplastic blended with $\mathrm{K}_{2} \mathrm{Cr}_{2} \mathrm{O}_{7}$, the CI values exhibited the same trend of those free of the $\mathrm{K}_{2} \mathrm{Cr}_{2} \mathrm{O}_{7}$ in which they increased from $22.9 \%$ for pure GA up to $51.9 \%$ for pure PVA. Comparing the two groups of bioplastic membranes (with and without $\mathrm{K}_{2} \mathrm{Cr}_{2} \mathrm{O}_{7}$ ) for their CI property revealed that adding the $\mathrm{K}_{2} \mathrm{Cr}_{2} \mathrm{O}_{7}$ to the GA/PVA blends decreased their CI by about $2 \%$ although there are no statistical difference between them (Figure 2). Within each group of the bioplastic blends, the increase occurred in the crystallinity of blends can be attributed to the increasing the allocate of the PVA in the bioplastic membranes [35] as shown in Figure 2.

\subsection{Thermal Analysis}

Thermal Analysis (TGA and DTA) was applied to detect the thermal behaviour of the twelve bioplastic membranes as affected by an external change in temperature.

\subsection{Thermogravimetric Analysis (TGA)}

The TGA measures the mass loss of the bioplastic membranes as a function of temperature and time, in a controlled atmosphere. It was to determine thermal stability and degradation characteristics of the materials examined.

For the bioplastic samples free of the $\mathrm{K}_{2} \mathrm{Cr}_{2} \mathrm{O}_{7}$, it is clear from Table 3 that thermal degradation of the bioplastic samples occurred at the higher temperatures $\left(300-500^{\circ} \mathrm{C}\right)$ was higher than that at the lower temperatures $\left(25-300^{\circ} \mathrm{C}\right)$. Comparing the mass losses within the temperature regions showed that PVA lost more weight (37.18 \% and 32.4\%) than that for the GA (18.9\% and $16.4 \%)$ at the higher temperature zones $\left(300^{\circ}-400^{\circ} \mathrm{C}\right.$ and $400^{\circ}-500^{\circ} \mathrm{C}$, respectively). The mass loss occurred up to $100^{\circ} \mathrm{C}$ can be attributed to evaporation of free water from the samples [35,44]. On the other hand, evaporation of hygroscopic water is responsible to the mass loss occurred at about to $150^{\circ} \mathrm{C}[35,44]$. In addition, for the bioplastic samples doped with $\mathrm{K}_{2} \mathrm{Cr}_{2} \mathrm{O}_{7}$, the mass loss property had the same trend for those samples blended without $\mathrm{K}_{2} \mathrm{Cr}_{2} \mathrm{O}_{7}$ whereby they lose more weight at the higher temperatures (Table 3). In addition, adding the $\mathrm{K}_{2} \mathrm{Cr}_{2} \mathrm{O}_{7}$ to the bioplastic blends enhances the mass loss at the higher temperatures. Comparisons within each group of the blends (without and with $\mathrm{K}_{2} \mathrm{Cr}_{2} \mathrm{O}_{7}$ ), doping the $\mathrm{K}_{2} \mathrm{Cr}_{2} \mathrm{O}_{7}$ in the formulas enhances the mass loss for the GA-based membranes, while the inverse result was obtained for the pure PVA membranes except for the temperature region $200^{\circ}-300^{\circ} \mathrm{C}$ (Table 3). 


\subsection{Differential Thermal Analysis (DTA)}

The DTA measures the temperature difference of the sample versus a reference, caused by thermal events in a material. It provides similar information to DSC. DTA usually complements TGA with phase transition information.

The DTA results of the six bioplastic are presented in Table 4 and Figure 3. Comparing the thermograms of pure GA and PVA membranes (GA/PVA=0/1 and $1 / 0$, respectively) revealed that the GA thermogram was differentiated into two distinct regions (endotherm and exotherm), while the PVA thermogram had a unique thermal state termed as endotherm. In addition, the bioplastic thermograms of GA/PVA of $1 / 0.5$, and $1 / 0.75$ had both endo-and exotherms, while GA/PVA blends of $1 / 0.25$, and $1 / 1$ had a unique endotherm. For more details, the temperature range of each thermogram and the maximum temperature of the six bioplastic blends are presented in Table 4 . In addition, the absolute values of the heat change values for the endotherms ranged from $1017.3 \mu \mathrm{Vs} / \mathrm{mg}$ to $2268.8 \mu \mathrm{Vs} / \mathrm{mg}$ and were higher than those for the exotherms ( $16 \mu \mathrm{Vs} / \mathrm{mg}-52.4 \mu \mathrm{Vs} / \mathrm{mg})$. In addition, the endotherm of the pure PVA (Formula no. 6) absorbed the highest energy (2119.7 $\mu \mathrm{Vs} / \mathrm{mg})$ among the other bioplastic blends, while the GA had the lowest value of the heat change $(-1017.3 \mu \mathrm{Vs} / \mathrm{mg})$. The overall energy absorbed up to $500^{\circ} \mathrm{C}$ and subsequently thermal stability of the bioplastic membranes were increased as the PVA allocation in the blend is increased although the mass loss has the same trend. Accordingly, the PVA is more thermally stable than the GA due to its higher absorption of the heat released that prevents the bioplastic sample from probable thermal degradation caused by increasing temperature. In addition, the thermal stability of the bioplastic membranes was increased with the increasing in the PVA allocation in the blends.

Comparing the heat change extracted from the DTAthermogram of pure GA (Figure 3a, and Table 4) revealed that without $\mathrm{K}_{2} \mathrm{Cr}_{2} \mathrm{O}_{7}$, the thermogram was divided into two divisions, namely exothermic sub-peak (arisen between $321^{\circ} \mathrm{C}-433^{\circ} \mathrm{C}$ ) and endothermic sub-peak appeared at $31^{\circ} \mathrm{C}$ and $321^{\circ} \mathrm{C}$ ). In addition, the DTA-thermogram doped with $\mathrm{K}_{2} \mathrm{Cr}_{2} \mathrm{O}_{7}$ exhibited one endothermic sub-peak arisen from $32^{\circ} \mathrm{C}$ to $487^{\circ} \mathrm{C}$ (Figure 3b). Accordingly, adding the $\mathrm{K}_{2} \mathrm{Cr}_{2} \mathrm{O}_{7}$ to the pure GA solution modified its differential thermal behavior whereby the exothermic reactions occurred between $321^{\circ} \mathrm{C}$ and $433^{\circ} \mathrm{C}$ were disappeared.

In addition, as shown in Table 4, the $\mathrm{K}_{2} \mathrm{Cr}_{2} \mathrm{O}_{7}$ increased the heat change formed upon heat exposure drastically for all the bioplastic blends. For more illustration, the absorbed heat by the endotherms due to addition of the $\mathrm{K}_{2} \mathrm{Cr}_{2} \mathrm{O}_{7}$ were increased from 1017 to 6310, from 2269 to 4062, from 1128 to 3600, from 1276 to 3500, from 1467 to 3309 , and from 2120 to 2952 for the AG/PVA formulas of $1 / 0,1 / 0.25,1 / 0.5,1 / 0.75,1 / 1$, and $0 / 1$, respectively. Increasing the heat absorbed by such a bioplastic blend is useful to prevent its enthalpy to proceed into its thermal degradation point and subsequently enhance its thermal stability.

Table 3. Mean values of mass loss (\%) of the twelve bioplastic membranes blended from gum Arabic (GA) and polyvinyl alcohol (PVA) with the different ratios in absence and presence of potassium dichromate $\left(\mathrm{K}_{2} \mathrm{Cr}_{2} \mathrm{O}_{7}\right)$.occurred upon thermal exposure up to $500{ }^{\circ} \mathrm{C}$

\begin{tabular}{|c|c|c|c|c|c|c|c|c|}
\hline \multirow{2}{*}{ AG/PVA } & \multicolumn{2}{|c|}{$100^{\circ}-200^{\circ} \mathrm{C}$} & \multicolumn{2}{|c|}{$200^{\circ}-300^{\circ} \mathrm{C}$} & \multicolumn{2}{|c|}{$300^{\circ}-400^{\circ} \mathrm{C}$} & \multicolumn{2}{|c|}{$400^{\circ}-500^{\circ} \mathrm{C}$} \\
\hline & Non-chromated & chromated & Non-chromated & chromated & Non-chromated & chromated & Non-chromated & chromated \\
\hline $1: 0$ & 15.7 & 14.9 & 13.1 & 14.9 & 18.9 & 22.8 & 16.4 & 28.6 \\
\hline $1: 0.25$ & 10.4 & 10.3 & 12.5 & 17.9 & 25.4 & 23.9 & 18.7 & 28.8 \\
\hline $1: 0.5$ & 12.1 & 10.4 & 12.7 & 17.1 & 23.6 & 24 & 26.7 & 29.8 \\
\hline 1:0.75 & 12 & 10.8 & 9.4 & 16.3 & 34.5 & 24.4 & 22.6 & 33.9 \\
\hline $1: 1$ & 10.6 & 12.2 & 12.7 & 19.6 & 37.2 & 18.5 & 24.1 & 33.3 \\
\hline $0: 1$ & 16.6 & 9.9 & 8.7 & 33.7 & 37.18 & 7.6 & 32.4 & 30 \\
\hline
\end{tabular}

Table 4. Differential thermal analysis (DTA) output for temperature range (TR), maximum temperature (MT) and heat change (HG) of the twelve bioplastic membranes blended from gum Arabic (GA) and polyvinyl alcohol (PVA) with different ratios in absence and presence of potassium di-chromate $\left(\mathrm{K}_{2} \mathrm{Cr}_{2} \mathrm{O}_{7}\right)$ upon thermal exposure up to $500^{\circ} \mathrm{C}$

\begin{tabular}{|c|c|c|c|c|c|c|c|}
\hline \multirow{2}{*}{$\begin{array}{l}\text { Formula } \\
\text { AG/PVA }\end{array}$} & \multirow{2}{*}{$\begin{array}{l}\text { Sub-peak } \\
\text { No. }\end{array}$} & \multicolumn{2}{|c|}{$\operatorname{TR}\left({ }^{\circ} \mathrm{C}\right)$} & \multicolumn{2}{|c|}{$\operatorname{MT}\left({ }^{\circ} \mathrm{C}\right)$} & \multicolumn{2}{|c|}{ HG ( $\mu \mathrm{Vs} / \mathrm{mg})$} \\
\hline & & $\begin{array}{l}\text { Without } \\
\mathrm{K}_{2} \mathrm{Cr}_{2} \mathrm{O}_{7}\end{array}$ & $\begin{array}{c}\text { With } \\
\mathrm{K}_{2} \mathrm{Cr}_{2} \mathrm{O}_{7}\end{array}$ & $\begin{array}{l}\text { Without } \\
\mathrm{K}_{2} \mathrm{Cr}_{2} \mathrm{O}_{7}\end{array}$ & $\begin{array}{c}\text { With } \\
\mathrm{K}_{2} \mathrm{Cr}_{2} \mathrm{O}_{7}\end{array}$ & $\begin{array}{l}\text { Without } \\
\mathrm{K}_{2} \mathrm{Cr}_{2} \mathrm{O}_{7}\end{array}$ & $\begin{array}{c}\text { With } \\
\mathrm{K}_{2} \mathrm{Cr}_{2} \mathrm{O}_{7}\end{array}$ \\
\hline $1: 0$ & $\begin{array}{l}\text { Endotherm } \\
\text { Exotherm } \\
\end{array}$ & $\begin{array}{c}31-321 \\
321-433 \\
\end{array}$ & $\begin{array}{c}32-487 \\
- \\
\end{array}$ & $\begin{array}{l}106 \\
407 \\
\end{array}$ & $\begin{array}{c}280 \\
- \\
\end{array}$ & $\begin{array}{c}-1017 \\
+52 \\
\end{array}$ & $\begin{array}{c}-6310 \\
- \\
\end{array}$ \\
\hline $1: 0.25$ & Endotherm & $32-500$ & $43-471$ & 114 & 275 & -2269 & -4062 \\
\hline \multirow{2}{*}{$1: 0.5$} & Endotherm & $45-421$ & $43-468$ & 119 & 275 & -1128 & -3600 \\
\hline & Exotherm & $421-500$ & $468-500$ & 465 & 443 & -17 & +189 \\
\hline \multirow{2}{*}{$1: 0.75$} & Endotherm & $48-389$ & $32-430$ & 127 & 276 & -1276 & -3500 \\
\hline & Exotherm & $3089-500$ & $430-491$ & 422 & 450 & -29 & +177 \\
\hline \multirow{2}{*}{$1: 1$} & Endotherm & $41-384$ & $32-433$ & 123 & 273 & -1467 & -3309 \\
\hline & Exotherm & - & $433-500$ & - & 458 & - & +132 \\
\hline \multirow{2}{*}{$0: 1$} & Endotherm & $45-438$ & $136-422$ & 220 & 228 & -2120 & -2952 \\
\hline & Exotherm & - & $422-500$ & - & 467 & - & -108 \\
\hline
\end{tabular}



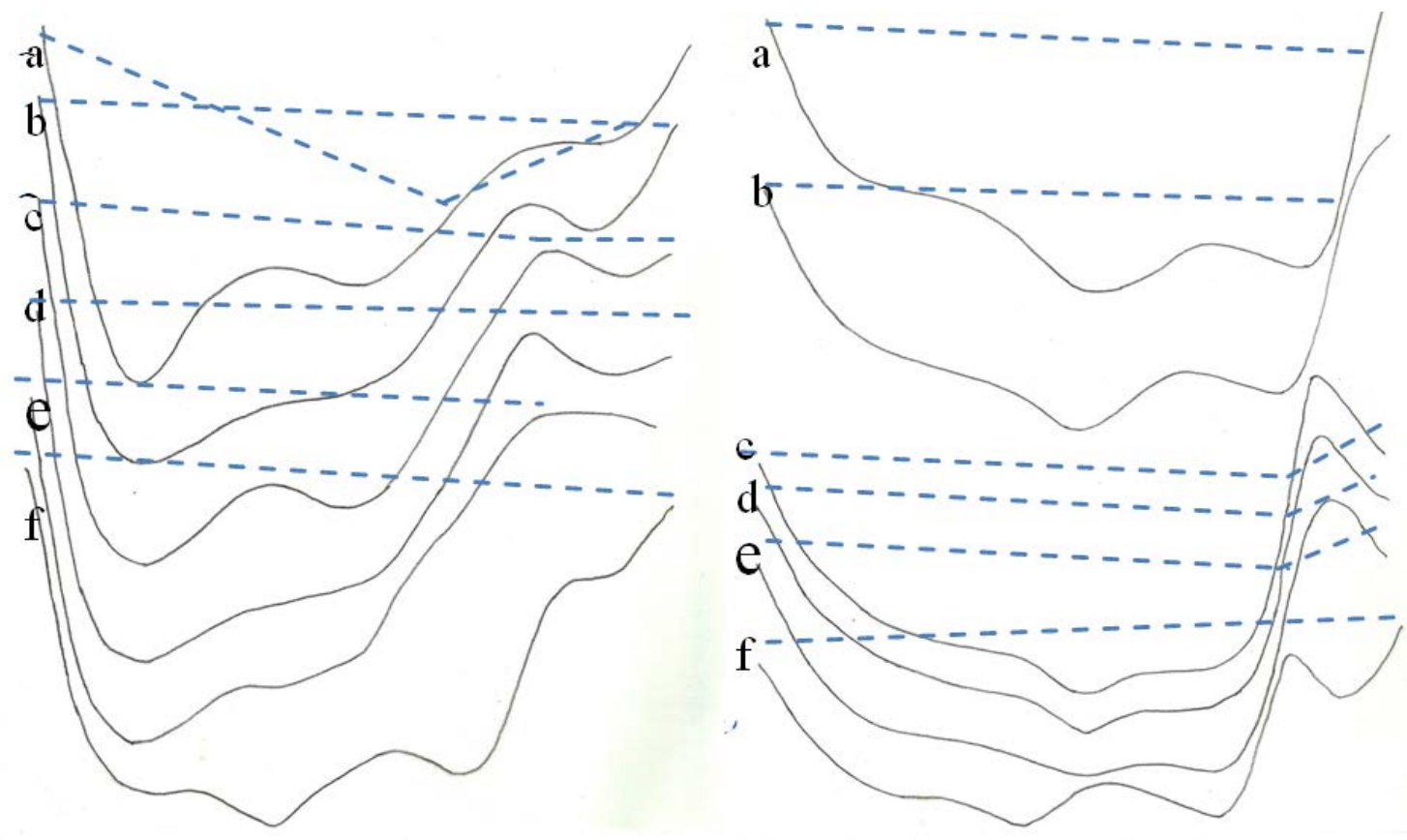

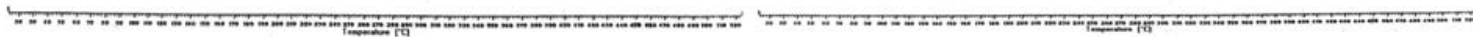

Figure 3. Differential thermal analysis (DTA) thermograms of the twelve bioplastic membranes blended from gum Arabic (GA) and polyvinyl alcohol (PVA) with different ratios in absence and presence of potassium dichromate $\left(\mathrm{K}_{2} \mathrm{Cr}_{2} \mathrm{O}_{7}\right)$ in temperature range from $25-500^{\circ} \mathrm{C}$ : a-f) GA/PVA ratios: a) $1 / 0$, b) $1 / 0.25$, c) $1 / 0.5$, d) $1 / 0.75$, e) $1 / 1$ and $0 / 1$

Table 5. Some statistic parameters, namely maximum value (Max.), mean, observations number (ON) and standard deviation (SD) of particle size and void volume of the bioplastic membranes blended from gum Arabic (GA) and polyvinyl alcohol (PVA) with and without potassium dichromate $\left(\mathrm{K}_{2} \mathrm{Cr}_{2} \mathrm{O}_{7}\right)$

\begin{tabular}{|c|c|c|c|c|c|}
\hline \multirow{2}{*}{$\begin{array}{l}\text { AG/PVA } \\
\text { ratio }\end{array}$} & \multirow{2}{*}{$\begin{array}{c}\text { Statistic } \\
\text { parameters }\end{array}$} & \multicolumn{2}{|c|}{ Particle size (nm) } & \multicolumn{2}{|c|}{ Void Volum $\left(\mathrm{nm}^{3}\right)$} \\
\hline & & $\begin{array}{l}\text { Without } \\
\mathrm{K}_{2} \mathrm{Cr}_{2} \mathrm{O}_{7} \\
\end{array}$ & $\begin{array}{c}\text { With } \\
\mathrm{K}_{2} \mathrm{Cr}_{2} \mathrm{O}_{7} \\
\end{array}$ & $\begin{array}{l}\text { Without } \\
\mathrm{K}_{2} \mathrm{Cr}_{2} \mathrm{O}_{7} \\
\end{array}$ & $\begin{array}{c}\text { With } \\
\mathrm{K}_{2} \mathrm{Cr}_{2} \mathrm{O}_{7} \\
\end{array}$ \\
\hline \multirow{4}{*}{$1: 0$} & Max. & 55.4 & 71.3 & 8989 & 6828 \\
\hline & Mean & 13.7 & 15.7 & 101.9 & 92 \\
\hline & SD & 7.71 & 8.8 & 468 & 394 \\
\hline & ON & 1293 & 986 & 1111 & 986 \\
\hline \multirow{4}{*}{$1: 0.25$} & Max. & 76.9 & 93.5 & 1886 & 5458 \\
\hline & Mean & 14.2 & 19.2 & 89 & 229 \\
\hline & SD & 8.7 & 13.8 & 209 & 483 \\
\hline & ON & 1153 & 572 & 1231 & 572 \\
\hline \multirow{4}{*}{ 1:0.5 } & Max. & 67 & 79.9 & 5219 & 3392 \\
\hline & Mean & 14.4 & 13.89 & 73 & 120 \\
\hline & SD & 8.15 & 9.6 & 282 & 250 \\
\hline & ON & 1167 & 1117 & 1175 & 1117 \\
\hline \multirow{4}{*}{$1: 0.75$} & Max. & 72.3 & 56.8 & 10081 & 1033 \\
\hline & Mean & 16.9 & 12.2 & 138 & 61 \\
\hline & SD & 9.25 & 7.1 & 647 & 96 \\
\hline & ON & 865 & 1600 & 697 & 1600 \\
\hline \multirow{4}{*}{$1: 1$} & Max. & 77 & 52.6 & 74927 & 2827 \\
\hline & Mean & 19 & 12.3 & 520 & 55 \\
\hline & SD & 12 & 6.3 & 3660 & 174 \\
\hline & ON & 634 & 1667 & 580 & 1667 \\
\hline \multirow{4}{*}{$0: 1$} & Max. & 89.8 & 116 & 24725 & 11541 \\
\hline & Mean & 18.9 & 47.2 & 415 & 2793 \\
\hline & SD & 14.5 & 24.8 & 1705 & 2491 \\
\hline & ON & 564 & 113 & 530 & 113 \\
\hline
\end{tabular}



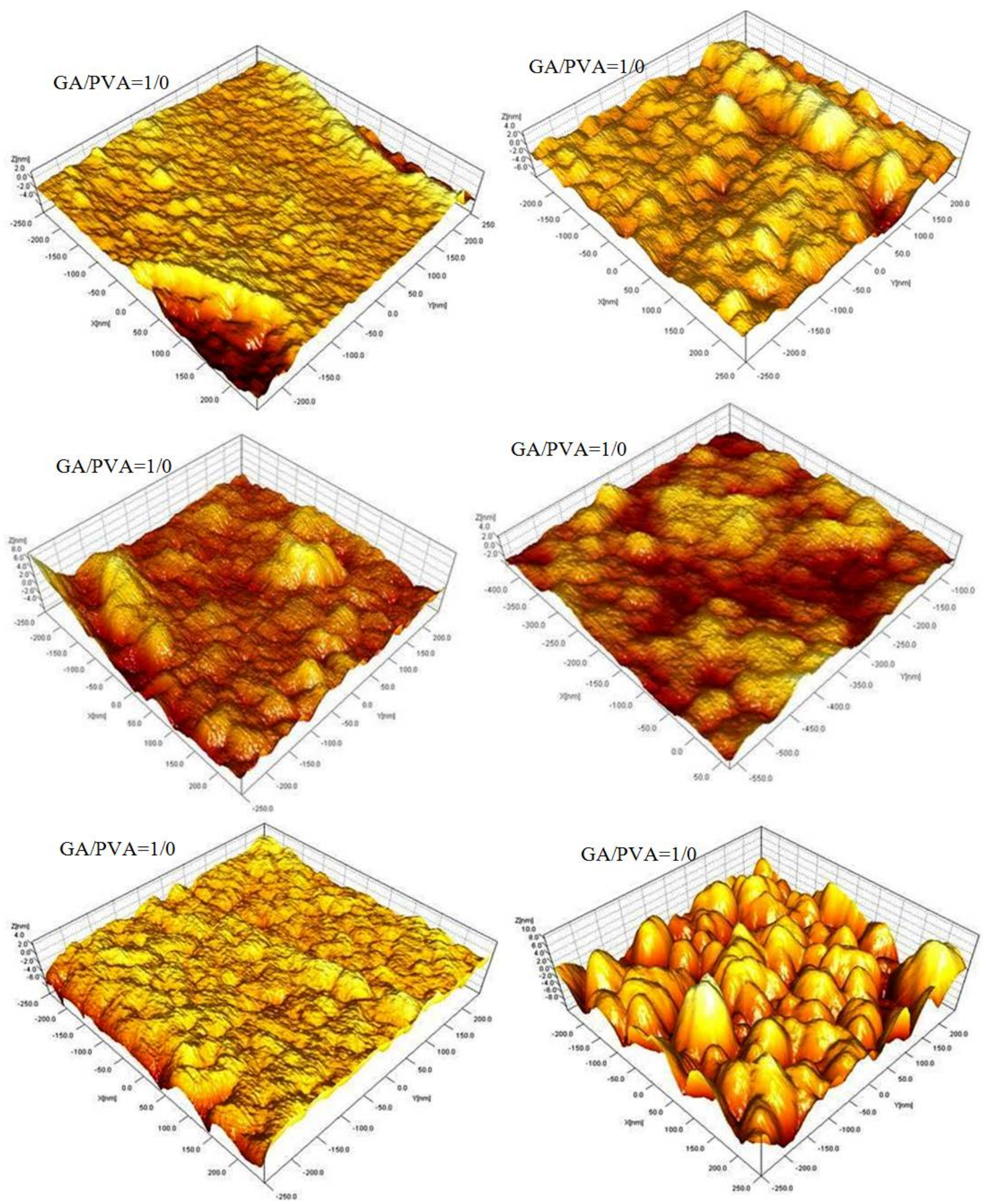

Figure 4. AFM images showing surface roughness of the twelve bioplastic membranes blended from gum Arabic (GA) and polyvinyl alcohol (PVA) with the different ratios in absence and presence of potassium di-chromate $\left(\mathrm{K}_{2} \mathrm{Cr}_{2} \mathrm{O}_{7}\right)$ : a-f) GA/PVA ratios: a) 1/0, b) 1/0.25, c) 1/0.5, d) 1/0.75, e) 1/1 and $0 / 1$

\subsection{Nanometric Particle Size (NPS)}

For the nanometric particle size (NPS) of the two groups of bioplastic membranes (doped and non-doped with $\mathrm{K}_{2} \mathrm{Cr}_{2} \mathrm{O}_{7}$ ) presented at Table 5, comparisons between groups revealed that the non-doped- $\mathrm{K}_{2} \mathrm{Cr}_{2} \mathrm{O}$ pure GA membrane had slightly lower NPS than that for the doped one each of mean (13.69 $\mathrm{nm}$ and $15.7 \mathrm{~nm}$, respectively) and maximum values (55.4 nm, $71.3 \mathrm{~nm}$, respectively). In addition, the non-doped- $\mathrm{K}_{2} \mathrm{Cr}_{2} \mathrm{O}$ pure PVA membrane had lower NPS values (18.9 and $89.8 \mathrm{~nm}$ for mean and maximum values, respectively) than that for doped one (47.7 and $116 \mathrm{~nm}$ for mean and maximum values, respectively). Accordingly, adding $\mathrm{K}_{2} \mathrm{Cr}_{2} \mathrm{O}_{7}$ to the pure 
PVA-based bioplastic blends (GA/PVA-0/1) increased the NPS significantly, while this effect is not clear for the other blends.

Comparisons within the group revealed that increasing the PVA concentration in a blend had a greater effect than did $\mathrm{K}_{2} \mathrm{Cr}_{2} \mathrm{O}_{7}$ on the NPS. Accordingly, increasing the PVA concentration in the bioplastic blends increased the NPS gradually. This can be confirmed by the surface roughness features investigated by atomic force microscope (AFM) as shown in Figure 4.

\subsection{Biodegradation Bacteria and Fungi}

The microbial population's species data of the colony forming units (CFU) are presented in Table 6. The numbers of bacteria and fungi in the initial soil sample were found to be $2.11 \times 10^{5}$ and $1.3 \times 10^{2} \mathrm{CFU} / \mathrm{ml}$, respectively and were lower than that for the chromated GA and greater than that for the chromated PVA (Table 6). The CFU of the chromated pure GA $(\mathrm{GA} / \mathrm{PVA}=1 / 0)$ was greater than that for the chromated pure PVA (GA/PVA=0/1) after 30 and 60 days. This means that the GA substrate is more preferred as a nutrient supply for these microorganisms. Also, there were no clear differences in the CFU values obtained after 30 and 60 days for all the six bioplastic membranes.

Table 6. Colony forming units (CFU) of microbial populations for bacterial and fungal species in the six buried bioplastic membranes blended from chromated gum Arabic and polyvinyl alcohol with the different GA/PVA ratios of $1 / 0,1 / 0.25,1 / 0.5,1 / 0.75,1 / 1$ and $0 / 1$ as compared with the control soil samples

\begin{tabular}{|c|c|c|c|c|}
\hline \multirow{3}{*}{$\begin{array}{c}\text { Chromated AG/ } \\
\text { PVA ratio }\end{array}$} & \multicolumn{4}{|c|}{$\mathrm{CFU} / \mathrm{ml}$} \\
\hline & \multicolumn{2}{|c|}{ After 30 days } & \multicolumn{2}{|c|}{ After 60 days } \\
\hline & Bacteria & Fungi & Bacteria & Fungi \\
\hline $1 / 0$ & $2.51 \times 10^{5}$ & $1.51 \times 10^{2}$ & $2.33 \times 10^{5}$ & $1.42 \times 10^{2}$ \\
\hline $1 / 0.25$ & $2.11 \times 10^{5}$ & $1.35 \times 10^{2}$ & $1.98 \times 10^{5}$ & $1.37 \times 10^{2}$ \\
\hline $1 / 0.5$ & $2.14 \times 10^{5}$ & $1.37 \times 10^{2}$ & $2.00 \times 10^{5}$ & $1.38 \times 10^{2}$ \\
\hline $1 / 0.75$ & $2.22 \times 10^{5}$ & $1.44 \times 10^{2}$ & $2.32 \times 10^{5}$ & $1.41 \times 10^{2}$ \\
\hline $1 / 1$ & $2.43 \times 10^{5}$ & $1.47 \times 10^{2}$ & $2.45 \times 10^{5}$ & $1.43 \times 10^{2}$ \\
\hline $0 / 1$ & $1.89 \times 10^{5}$ & $1.4 \times 10^{2}$ & $1.73 \times 10^{5}$ & $1.16 \times 10^{2}$ \\
\hline $0 / 0$ & $2.11 \times 10^{5}$ & $1.3 \times 10^{2}$ & $2.18 \times 10^{5}$ & $1.5 \times 10^{2}$ \\
\hline
\end{tabular}

The buried bioplastic membranes in the initial soil samples had different number and species of microbial communities. There were different species of bacteria and fungi according to the type of buried membrane and the concentration of the polymer. The buried chromated pure PVA membrane, the dominant species were Bacillus spp [25,45,46,47,48,49], Pseudomonas spp [27,31,50,47,48], Aspergillus spp [51] and Penicillium spp [27,47]. In addition, for the buried GA, the major species were Bacillus spp [6,12,45], Penicillium spp, Aspergillus spp, Rhizorpous spp, [6,33,34]. This results agree with Coleman and Paran [52] who concluded that Gram-negative chromium reducing-bacteria tend to be more sensitive to chromium ion, while Gram positive bacteria are significantly tolerant to chromate ion toxicity even at relatively high concentration of the ion [25,52]. Moreover, the microbial communities of the bioplastic blends, namely (chromated GA/PVA=1:1), (chromated GA/PVA=1:0.75), (chromated
GA/PVA=0.5) and (GA/PVA=1:0.25) contained Bacillus spp [25,45,46,49,53], Pseudomonas spp [27,31,47,48,50], Aspergillus spp, Rhizorpous spp, and Penicillium spp. [33]. It is worth to mention that Pseudomonas spp. are well-characterized heterotrophs known to degrade several hydrocarbons [5,6,7,40], and reduce metals such as Cr (VI) due to these bacteria can use the PVA as a source of carbon.

Also, it is very clear that the detected bacterial species were more than fungal which is not agreed with Mergaert et al. [38] who found that the fungal isolates had high capability of utilizing his the membranes as a growth substrate than bacterial isolates. The PVA is a vinyl polymer where the main chain is joined by only one carbon-carbon linkage $\left(-\mathrm{CH}_{2}-\mathrm{CHOH}-\right)_{\mathrm{n}}$ and this considered to be a good source of carbon for different bacterial and fungi species which leads to increase in cell growth and number [54]. On the other hand, GA is a branched-chain, complex polysaccharide which also is considered to be a good source of carbon for microorganisms [6]. Furthermore, PVA and GA may blended together or with other polymers to improve their biodegradability and mechanical properties which is explain the high numbers of bacterial and fungal species on the blended membranes respectively (chromated GA/PVA=1:0.25), (chromated GA/PVA=1:0.5), chromated GA/PVA=1:0.75), and (chromated GA/PVA) comparing to the number of different microorganisms on the initial soil sample. In addition, the most number of microorganisms species was appeared with GA, and the low number was with PVA $[9,10,11,12,55]$. In this study, all bacterial and fungi species had a growth ability and are expected to be detoxification tools of potassium dichromate that blended with GA and PVA or both which leads to reduce the high absorption rate of chromium ion by animal, plant, and algae cells in the soil and enhancing the biodegradation of bioplastic membranes [25]. No yeast cells found in our samples and this is not agree with Jadhav et al. [33] who proved that yeast are capable to reduce the toxicity of the dye in the environment to the permissible limit of discharge.

\section{Conclusions}

- All the maximum intensities of the bioplastic membranes doped with $\mathrm{K}_{2} \mathrm{Cr}_{2} \mathrm{O}_{7}$ were obtained around $2 \theta=19^{\circ}$ except for the gum Arabic-diffractogram that was shifted to $2 \theta=22.34^{\circ}$.

- Pure polyvinyl alcohol known as a semi-crystalline polymer exhibited a sharper peak at $2 \theta=19.9^{\circ}$.

- Adding potassium dichromate to the gum Arabic/polyvinyl alcohol blends had a minor effect on reducing their crystallinity index and the increase in the crystallinity of blends can be attributed to the increasing the concentration of the polyvinyl alcohol in the bioplastic membranes.

- Adding potassium dichromate to the pure gum Arabic solution modified its differential thermal behavior whereby the exothermic reactions occurred between $321^{\circ} \mathrm{C}$ and $433^{\circ} \mathrm{C}$ were disappeared.

- Potassium dichromate increased the heat change formed upon heat exposure drastically for all the 
bioplastic blends with the highest increase for the pure gum Arabic samples.

- Adding potassium dichromate to the pure polyvinyl alcohol blends increased the nanometric particle size significantly, while this effect is not clear for the other blends.

- Increasing the polyvinyl alcohol concentration in a blend had a greater effect than the potassium dichromate on the nanometric particle size of the bioplastic samples.

- The buried bioplastic membranes in the initial soil samples had different number and species of microbial communities.

- The numbers of bacteria and fungi in the initial soil sample were lower than those for chromated gum Arabic membranes and were greater than those for the chromated polyvinyl alcohol.

- The buried chromated pure polyvinyl alcohol membrane, the dominant species were Bacillus spp, Pseudomonas spp, Aspergillus spp and Penicillium spp.

- For the buried chromated pure gum Arabic, the major species were Bacillus spp, Penicillium spp, Aspergillus spp and Rhizorpous spp

- The colony forming unit of the chromated pure gum Arabic was greater than that for the chromated pure polyvinyl alcohol which means that the GA substrate is more preferred as a nutrient supply by these microorganisms.

- There were no clear differences in the colony forming units obtained after 30 and 60 days for all the six chromated bioplastic membranes.

- All bacterial and fungi species had a growth ability and are expected to be detoxification tools of chromium ion that blended with GA and PVA which leads to reduce the high absorption rate of this ion by animal, plant, and algae cells in the soil and enhancing the biodegradation of bioplastic membranes.

\section{Acknowledgments}

This project was funded by the Deanship of Scientific Research (DSR), King Abdulaziz University, Jeddah under grants no. 85/155/1434 and, respectively. The authors therefore, acknowledge with thanks the DSR for technical and financial support.

\section{References}

[1] Khan, J. A., Khan, M. A., Islam, R., and Abdul Gafur. 2010. Mechanical, thermal and interfacial properties of jute fabricreinforced polypropylene composites: Effect of potassium dichromate. Materials Sciences and Applications, 1 (6): 350-357.

[2] Wang, B.-Q., Zhang, P.-H., and Fang, M.-H. 2014. Potassium dichromate surface modification of poly-lactic acid (PLA) and poly-lactide-co-glycolide (PGLA) fibers. Advanced Materials Research, 936: 801.

[3] Crompton, T. R. 2012. Practical polymer analysis. Springer, US, 822 pp.

[4] James, C. 2008. The book of alternative photographic processes. Cengage Learning, USA. $2^{\text {ed }}, 660$ pp.
[5] Chen, J., Zhang, Y., Du, G. C., Hua, Z. Z., and Zhu, Y. 2007. Biodegradation of polyvinyl alcohol by a mixed microbial culture. Enzyme Microb. Technol, 40 (7): 1686-1691.

[6] Abd Alla, F. A. A. 2012. The Effects of Microbiological Biodegradation on Gum Arabic Structure and Molecular Mass, PhD Thesis, Sudan University of Science and Technology): 147 pp.

[7] Azzaoui, K., Hammouti, B., Lamhamdi, A., Mejdoubi, E., and Berrabah, M. 2014. The Gum Arabic in the southern region of Morocco. Moroccan Journal of Chemistry, 3(1): 99-107.

[8] Razzak, M. T., and Darwis, D. 2001. Irradiation of polyvinyl alcohol and polyvinyl pyrrolidone blended hydrogel for wound dressing. Radiat. Phys. Chem., 62(1): 107-113.

[9] Nair, N. R., Nampoothiri, K. M., and Pandey, A. 2012. Preparation of poly (L-lactide) blends and biodegradation by Lentzea waywayandensis. Biotechnol. Lett, 34 (11): 2031-2035.

[10] Onyari, J. M., Mulaa, F., Muia, J., and Shiundu, P. 2008. Biodegradability of poly (lactic acid), preparation and characterization of PLA/gum Arabic blends. Journal of Polymers and the Environment, 16 (3): 205-212.

[11] Tiwari, A., Terada, D., and Kobayash, H. 2011. Polyvinyl Modified Guar-gum Bioplastics for Packaging Applications. Handbook of Bioplastics and Biocomposites Engineering Applications, 24: 177.

[12] Padil, V. V. T., Nguyen, N. H., Ševců, A., and Černík, M. 2015. Fabrication, characterization, and antibacterial properties of electrospun membrane composed of gum karaya, polyvinyl alcohol, and silver nanoparticles. Journal of Nanomaterials, 271: 32-38.

[13] Falath, W., Sabir, A., Jacob, K. I. 2017. Novel reverse osmosis membranes composed of modified PVA/Gum Arabic conjugates: Biofouling mitigation and chlorine resistance enhancement. Carbohydr Polym., 155: 28-39.

[14] Mollasalehi, S. 2013. Fungal biodegradation of polyvinyl alcohol in soil and compost environments.PhD thesis. University of Manchester. 156 pp.

[15] Wang, X. F., Xing, M.L., Shen, Y., Zhu, X., and Xu, L.H. 2006. Oral administration of $\mathrm{Cr}(\mathrm{VI})$ induced oxidative stress, DNA damage and apoptotic cell death in mice. Toxicology, 228: 16-23.

[16] Kim, E. and K.J. Na, 1991. Nephrotoxicity of sodium dichromate depending on the route of administration. Arch. Toxicol., 65: 537-541.

[17] Poornima, K., Karthik, L., Swadhini, S. P., Mythili, S., and Sathiavelu, A. 2010. Degradation of chromium by using a novel strains of Pseudomonas species. J Microbial Biochem Technol., 2: 95-99.

[18] Tchounwou, P. B et al. 2017. Heavy metals toxicity and the environment. EXS 101 (2012): 133-164. PMC.

[19] Anonymous. WHO/FAO/IAEA. World Health Organization. Switzerland: Geneva. 1996. Trace Elements in Human Nutrition and Health.

[20] Squadrone, S., Burioli, E., Monaco, G., Koya, M. K., Prearo, M., Gennero, S., and Abete, M. C. 2016. Human exposure to metals due to consumption of fish from an artificial lake basin close to an active mining area in Katanga (DR Congo). Science of The Total Environment, 568: 679-684.

[21] Assasa, M. F., and Farahat, M. M. I. 2014. Toxic Effect of Potassium Dichromate on Sex Hormones and Possible Protective Effect of Rice Bran Oil in Female Albino Rats. Journal of Pharmacology and Toxicology, 9: 90-96.

[22] Shi, X., Chiu, A., Chen, C. T., Halliwell, B., Castranova, V., and Vallyathan, V. 1999. Reduction of chromium (VI) and its relationship to carcinogenesis. J. Toxicol. Environ. Health Part B: Crit. Rev., 2: 87-104.

[23] Banu, S. K., J. B. Samuel, J. A. Arosh, R. C. Burghardt and M.M. Aruldhas, 2008. Lactational exposure to hexavalent chromium delays puberty by impairing ovarian development, steroidogenesis and pituitary hormone synthesis in developing Wistar rats. Toxicol. Applied Pharmacol., 232: 180-189.

[24] Francis, A. J., Spanggord, R. J., Ouchi, G. I., Bramhall, R., and Bohonos, N. 1976. Metabolism of DDT Analogues by a Pseudomonas sp. Appl Environ Microbiol., 32: 213-216. 
[25] Algamdi, A. Y., Alharbi, S. A., Wainwright, M., and Al-Solaimani, S. G. 2016 . Isolation and Identification of Nine Dichromate $\mathrm{Cr}^{+6}$ resistance Bacteria by Modern Techniques. Journal of Scientific and Engineering Research, 3(4): 383-391.

[26] Thakur, I. S., \& Srivastava, S. 2011. Biodegradation and bioconversion of chromium and pentachlorophenol in tannery effluent by microorganisms. Int J Technol, 3: 224-233.

[27] Chakraborty, R., Woo, H., Dehal, P., Walker, R., Zemla, M., Auer, M., and Hazen, T. C. 2017. Complete genome sequence of Pseudomonas stutzeri strain RCH2 isolated from a Hexavalent Chromium [Cr (VI)] contaminated site. Standards in Genomic Sciences, 12 (1): 23.

[28] Masood, F., and Malik, A. 2011. Hexavalent chromium reduction by Bacillus sp. strain FM1 isolated from heavy-metal contaminated soil. Bulletin of environmental contamination and toxicology, 86 (1): 114-119.

[29] Ackerley, D. F., Gonzalez, C. F., Keyhan, M., Blake, R., \& Matin, A. 2004. Mechanism of chromate reduction by the Escherichia coli protein, NfsA, and the role of different chromate reductases in minimizing oxidative stress during chromate reduction. Environmental Microbiology, 6 (8): 851-860.

[30] McLean, J., \& Beveridge, T. J. 2001. Chromate reduction by a pseudomonad isolated from a site contaminated with chromated copper arsenate. Applied and Environmental Microbiology, 67 (3): 1076-1084.

[31] Kafilzadeh, F., and Saberifard, S. 2016. Isolation and identification of chromium (VI)-Resistant bacteria from Soltan Abad river sediments (Shiraz-Iran). Jundishapur Journal of Health Sciences, 8 (1): e33576.

[32] Ilias, M., Rafiqullah, I. M., Debnath, B. C., Mannan, K. S. B., \& Hoq, M. M. 2011. Isolation and characterization of chromium (VI)-reducing bacteria from tannery effluents. Indian journal of microbiology, 51 (1): 76-81.

[33] Jadhav, I., Vasniwal, R., Shrivastava, D., \& Jadhav, K. 2016. Microorganism-Based Treatment of Azo Dyes. Journal of Environmental Science and Technology, 9(2), 188.

[34] Varotkar, P., Tumane, P. M., \& Wasnik, D. D. 2016. Bioconversion of Waste Paper into Bio-Ethanol by Co-Culture of Fungi Isolated from Lignocellulosic Waste. Int. J. Pure App. Biosci., 4 (4): 264-274.

[35] Hindi, S. S. Z., Albureikan, M. O., Al-ghamdy, A. A, Alhummiany, H. and Ansari, M. S. 2017. Synthesis and characterization of Arabic gum based bio-plastic membranes. Nanoscience and Nanotechnology Research, 4 (1): 16-32.

[36] Hindi, S. S. Z. 2017 ${ }^{\mathrm{a}}$. Some Crystallographic Properties of Cellulose I as Affected by Cellulosic Resource, Smoothing, and Computation Methods. International Journal of Innovative Research in Science, Engineering and Technology (IJIRSET), 6 (1): 732-752.

[37] Fortunati, E., Puglia, D., Monti, M., Peponi, L., Santulli, C., Kenny, J. M. and Torre, L. 2013. Extraction of Cellulose Nanocrystals from Phormium tenax Fibres. Journal of Polymers and the Environment. 21(2): 319-328.

[38] Mergaert, J. Anderson, C. Wouters, A. Swings, J. and Kersters, K. F. E. M. S. 1992. Biodegradation of polyhydroxyalkanoates. FEMS Microbiology Letters, 103 (2-4): 317-321.

[39] Mostafa, H. M., Sourell, H., and Bockisch, F. J. 2010. Mechanical properties of some bioplastics under different soil types used as biodegradable drip tubes. Agricultural Engineering International: CIGR Journal, 12 (1): 12-21.

[40] Volova, T. G., Boyandin, A. N., Vasil'ev, A. D., Karpov, V. A., Kozhevnikov, I. V., Prudnikova, S. V., and Gitel'Zon, I. I. 2011 Biodegradation of polyhydroxyalkanoates (PHAs) in the South China Sea and identification of PHA-degrading bacteria. Microbiology, 80 (2): 252.

[41] El-Nakhlawy, F.S. 2008. Principles of statistics, biostatistical experimental design and analysis”. KAU Pub. Center. KSA.

[42] Bajpai, A. K., Shukla, S. K., Bhanu, S., and Kankane, S. 2008. Responsive polymers in controlled drug delivery. Progress in Polymer Science, 33 (11): 1088-1118.

[43] Rathna, G. V. N., Jog, J. P., and Gaikwad, A. B. 2011. Development of non-woven nanofibers of egg albumen-poly (vinyl alcohol) blends: influence of solution properties on morphology of nanofibers. Polym. J., 43 (7): 654-661.

[44] Hindi, S. S. Z. $2017^{\text {b}}$. Suitability of date palm leaflets for sulphated cellulose nanocrystals synthesis. Nanoscience and Nanotechnology Research, 4(1): 7-16.

[45] Algamdi, A. Y., Alharbi, S. A., Wainwright, M., and Al-Solaimani, S. G. 2016 . Detoxification of potassium dichromate $\left(\mathrm{Cr}^{6+}\right)$ by nine isolated bacteria species as affected by incubation periods. International Journal of Scientific \& Engineering Research, 7 (8).

[46] Rong, D., Usui, K., Morohoshi, T., Kato, N. O. R. I. H. I. R. O., Zhou, M., and Ikeda, T. S. U. K. A. S. A. 2009. Symbiotic degradation of polyvinyl alcohol by Novosphingobium sp. and Xanthobacter flavus. Journal of Environ. Biotechnol., 9 (2): 131-134.

[47] Mori, T., Sakimoto, M., Kagi, T., and Sakai, T. 1996. Isolation and characterization of a strain of Bacillus megaterium that degrades poly (vinyl alcohol). Biosci., Biotechnol., Biochem., 60 (2): 330-332.

[48] Patil, R., and Bagde, U. S. 2015. Enrichment and isolation of microbial strains degrading bioplastic polyvinyl alcohol and time course study of their degradation potential. African Journal of Biotechnology, 14 (27): 2216-2226.

[49] Sukumar, C., Janaki, V., Vijayaraghavan, K., Kamala-Kannan, S., \& Shanthi, K. 2017. Removal of Cr (VI) using co-immobilized activated carbon and Bacillus subtilis: fixed-bed column study. Clean Technologies and Environmental Policy, 19 (1): 251-258.

[50] Ismail, Z. Z., and Khudhair, H. A. 2016. Aerobic biodegradation of phenol by Immobilized Pseudomonas sp. cells in two different bio-carrier matrices. Journal of Engineering, 22 (4): 68-78.

[51] Jecu, L., Grosu, E., Raut, I., Ghiurea, M., Constantin, M., Stoica, A., and Vasilescu, G. 2012. Fungal degradation of polymeric materials: morphological aspects.

http://www.inginerie-

electrica.ro/acqu/2011/P_1_Fungal_degradation_of_polymeric_m aterials_Morfological_aspects.pdf.

[52] Coleman, R. N., Paran. J. H. 1983. Accumulation of hexavalent chromium by selected bacteria.Environ. Technol. Lett. 4: 149-156.

[53] Cadmus, M. C., Jackson, L. K., Burton, K. A., Plattner, R. D., and Slodki, M. E. 1982. Biodegradation of xanthan gum by Bacillus sp. Appl. Environ. Microbiol., 44 (1): 5-11. 81.

[54] Patil, R., \& Bagde, U. S. 2012. Isolation of polyvinyl chloride degrading bacterial strains from environmental samples using enrichment culture technique. African Journal of Biotechnology, 11 (31): 7947-7956.

[55] Leja, K., \& Lewandowicz, G. 2010. Polymer biodegradation and biodegradable polymers-a review. Polish Journal of Environmental Studies, 19 (2): 255-266. 